\title{
Visualisasi Tando Tabalah Penari Tunggal dalam Photomotion Pertunjukan Rampak Kelompok Tari Minang
}

\author{
Sri Rustiyanti, ${ }^{1}$ Wanda Listiani ${ }^{2}$ \\ 1, 2. Institut Seni Budaya Indonesia (ISBI) Bandung \\ Jl. Buahbatu No. 212 Bandung 40265 Jawa Barat Indonesia \\ E-mail : rustiyantisri@yahoo.com
}

\begin{abstract}
Pertunjukan tari adakalanya dibawakan oleh penari tunggal atau penari kelompok. Tari tunggal dilakukan oleh seorang penari memerankan seorang karakter atau tokoh. Bentuk tariannya berdiri sendiri dan tidak ada kaitannya dengan penampilan tari sebelumnya. Pertunjukan penari tunggal dituntut untuk tampil matang dan terampil, kemampuan virtuositas karena fokus perhatian yang terpusat pada satu orang saja, tentu saja berbeda dengan penari kelompok yang dituntut kerampakkan baik dalam garak (bentuk gerak) maupun garik (rasa gerak). Sifat tari tunggal menjadikan seseorang sebagai subjek sekaligus objek tarian yang dibawakannya. Adapun tari kelompok merupakan bentuk karya tari yang memerlukan kerja sama antarpenari, karena diperagakan lebih dari satu penari. Gerak penari satu dan penari lain saling berkaitan dan tidak dapat berdiri sendiri. Keseragaman untuk mencapai keindahan bentuk tari kelompok bukan hal yang mudah. Adapun hasil penelitian ini, dalam penyajian tari kelompok tando tabalah (identitas pribadi) harus lebur ditinggalkan dan ditanggalkan egoisme masing-masing pribadi penari.
\end{abstract}

Kata kunci: tando tabalah, penari tunggal, penari kelompok, photomotion

\section{The Visualisation of Tando Talabah Solo Dancer in Photomotion of Minang's Group Performing Dance}

\begin{abstract}
Occasionally, dance performance is performed by single dancer or a group dancers. Single dance is performed by a dancer performing a character of figure. The dance form is standing alone and doesn't have any relation with previous dance performance. The performance of single dance is required to perform satisfactorily and should have virtuous skill because the focus is only pointed at one person. It is different from a group dance that required for being systematic on motion and sense.The characteristic of single dance makes the dancer as the subject and the object of their performing dance. A group dance is the form of dance that required teamwork among dancers because it is performed by more than one dancer. The motion between one dancer and another is related and it cannot be standing alone.The uniformity in achieving the aesthetic in group dance is complicated.The result for this research shows that in group dance presentation, the personal identity must have dissolved and the egoism should have detached by each dancer.
\end{abstract}

Keywords: tando tabalah, Single dancer, Group dancer, photomotion. 


\section{PENDAHULUAN}

Tulisan ini merupakan hasil penelitian Kemenristek Hibah Kompetensi tahap lanjutan tahun ke-2. Penelitian Kompetensi tahun ke-1 merupakan pengembangan dari temuan penelitian disertasi yaitu estetika alua patuik raso-pareso (aparapa) yang diadopsi dari sebuah filosofi Minangkabau. Hasil penelitian tahun ke-1 mendokumentasikan estetika alua patuik raso pareso dalam bentuk photomotion representasi kemiripan figur manusia dalam bentuk dwimatra (seni rupa 2-dimensi). Dominasi manusia sebagai subjek foto membedakan jenis photomotion dengan yang lain. Photomotion memberikan indikasi personal baik pada pemilik potrait, subjek potrait maupun fotografer. Personalitas dalam fotografi menghadirkan ciri khas objek foto sekaligus fotografer. Foto gerak Tari Minang dalam photomotion tari memiliki daya levitasi visual. Daya levitasi visual estetika aparapa menarik antusiasme pemandang untuk merangsang pemunculan baik dalam imajinasi maupun keinginan seseorang untuk melakukan sesuatu. Photomotion aparapa mampu memunculkan pikiran, perasaan, dan intuisi penari sebagai model foto mencapai virtuositas sehingga daya levitasi visualnya menjadi besar. Daya hidup visual dari gerak tari akan muncul ketika gerak dimatikan sementara, gerak tari diberi jeda, terhenti sesaat. Resonansi imaji aparapa menjadi jelas dalam photomotion tari. Photomotion menggabungkan kecanggihan teknologi kamera dan rasa yang muncul dari sebuah gerak penari dan bidikan fotografer.

Estetika aparapa diadopsi dari kearifan lokal filosofi alua patuik raso pareso (aparapa). Filosofi aparapa tersebut menjadi pijakan dalam menetapkan dasar pemikiran untuk menetapkan level kualifikasi kemampuan penari dalam menyajikan sebuah tarian. Dasar tingkat kesulitan teknik gerak dan ekspresi Tari Minang dapat diklasifikasikan pada 3 level kualifikasi, yaitu: 1) Tingkat Alua, 2) Tingkat Patuik, dan 3) Tingkat Raso-Pareso. Keserasian ini menunjuk pada bentuk tubuh, karakter, ekspresi, serta berkaitan dengan teknik tari yang tidak lepas dari unsur-unsur keharmonisan gerak sesuai dengan bakat tando tabalah (identitas pribadi) penari tunggal dalam photomotion tari rampak kelompok.
Selanjutnya konsep aparapa ditransformasikan dalam budaya visualisasi tando tabalah (identitas pribadi) penari tunggal dalam photomotion tari rampak kelompok. Konsep ini merupakan gerakan improvisasi (spontanitas yang mampu mengendalikan ruang dan waktu), gerak yang selalu ada peluang untuk berkembang, gerak yang tidak pernah selesai, gerak yang selalu berproses, dan gerak yang berulang-ulang yang kemudian menjadi gerak milik sendiri. Groteks garik garinyiek sebagai sebuah estetika memiliki unsur yaitu pitunggue, membumi, dan dekat dengan alam. Pencapaian seorang penari diharapkan memiliki 'tubuh groteks garik garinyiek'. Eksplorasi bakat gerak yang dilakukan merupakan gerak corporal acrobatic (gerakan hebat dan yang mengagumkan berkenaan dengan ketangkasan tubuh), corporal impulses (gerakan atas desakan hati), virtuositas (kematangan teknik gerak yang luar biasa), dan improvisatif (kepekaan reflektivitas, spontanitas yang terlatih mampu mengendalikan ruang dan waktu). Tujuan penelitian ini mengimplementasikan estetika aparapa dalam photomotion penari kelompok. Perbedaan jumlah penari menentukan konsep visual photomotion. Hal ini dikarenakan penari tunggal bergerak dengan kesendirian dan virtuositas-nya, sedangkan penari kelompok bergerak dengan kerampakan dalam satu rasa dan satu bentuk.

Photomotion ragam gerak tubuh secara rampak kelompok yang umumnya menggabungkan ratusan frame gambar dalam satu cerita film bergerak dan disajikan dalam potongan-potongan sequence foto agar keindahan gerak aparapa foto bisa lebih dinikmati. Penelitian kompetensi ini merupakan gabungan seni plastis dan visual yang tidak hanya menampilkan esensi eidetik (gambaran bentuk imajinatif) semata, tetapi juga imaji kinetik dari momen gerak tari yang didasarkan pada khazanah tradisi Minang, terutama dalam kematangan aparapa. Pada batas-batas tertentu, photomotion ini memberikan gambaran kualitas kepenarian yang dapat dilihat dari pose, ekspresi, dan equilibrium harmoni dari sistem ketubuhan dari estetika sebuah local genius di Sumatra Barat. Photomotion, secara harfiah terbangun dari dua kata yaitu photo (foto) yang berarti gambar yang dihasilkan dari proses fotografis dan motion berarti gerakan/bergerak. Teknik ini secara prinsip menggunakan foto-foto atau frame by frame foto. Hasilnya selain didapatkan gambar diam foto-foto, sekaligus dapat juga 
dihasilkan film yang dibuat oleh gabungan foto-foto yang saling berhubungan satu sama lainnya. Hasilnya bisa saja menjadi sehalus sebuah film, tergantung banyaknya foto yang digabungkan dalam satu detik. Gerakannya patah-patah, tetapi menjadi sebuah pilihan yang tepat apabila digunakan untuk menganalisis gerak objeknya, karena objek tidak bergerak begitu cepat tapi terlihat seperti ada jeda di setiap gerakannya.

Oleh karena itu photomotion, dipilih untuk menganalisis estetika aparapa. Gerak-gerak tarian Minang direkam, dengan beragam sudut pengambilan, bisa seluruh badan atau closeup, bisa high angle, eye level atau low angle sehingga gesture, mimik dari para penari bisa terekam begitu detil dan halus. Cahaya selalu menjadi media yang abadi bagi fotografi. Karenanya seorang fotografer sejatinya menggunakan kuasa melihatnya, agar dapat membekukan cahaya ke dalam citra. Kamera pun menjadi medium mempersatukan antara subjek dan mata. Fotografi sebagai salah satu media, dipercaya mampu merekam beragam realitas. Realitas sebuah pertunjukan seni tidak terkecuali, oleh karena itu ekplorasi gerak tari yang begitu dinamis mampu direkam baik oleh fotografi.Teknik fotografi yang digunakan bisa dipakai untuk merekam gerak-gerak tari, langkah demi langkah, bisa dibuat beku gerakannya atau dibuat blur. Salah satu teknik yang sering digunakan dalam merekam gerak adalah dengan teknik photomotion.

Paradigma baru dalam proses kreatif yang terus memberikan perubahan bentuk, terungkap dalam aliran in and out actions yang diciptakan oleh tubuh dan berbagai ekspresivitas seni yang lain. Lebih jauh estetika aparapa sebagai konsep ternyata memiliki benang merah fenomena global yang sudah mulai dirintis dan memperlihatkan apa yang disebut dengan demokratisasi seni. Realitas fiksi keseharian menjadi sangat abu-abu, sekaligus batas genre seni yang satu dengan yang lain juga menjadi lebur dan mengristal dalam sebuah pertunjukan. Perpaduan dalam tari dan galeri photomotion, misalnya, bisa menjadi sebuah struktur yang secara sistemik mampu menyemaikan gagasan sebagai inkubator inovasi dalam proses kreatif berkesenian. Di sini terjadi pembentukan ataupun penciptaan, gagasan, potensi, kapasitas, serta ketrampilan, teknik dan kepekaan interdisiplin bidang apapun serta gagasan besar dalam cakupan silang budaya.

\section{METODE}

Penelitian ini adalah bersifat kualitatif, dengan demikian dasar yang dipakai untuk analisisnya adalah data, di mana kehadiran data harus ditempatkan sebagai sebuah totalitas (Soedarsono, 1999:

8-12). Sebuah bentuk penelitian kualitatif, data yang diperlukan dari berbagai sumber itu pun adalah berbentuk data kualitatif. Salah satu sifat dari data kualitatif adalah bahwa data itu merupakan data yang memiliki kandungan yang kaya, yang multi-dimensional, dan kompleks. Sebuah data kualitatif ibarat sebuah 'teka-teki' atau sebuah 'misteri'. Dalam menebak teka-teki itu selalu harus mengarah untuk menjawab pertanyaan 'mengapa', dan bukan sekadar menjawab pertanyaan 'apa' (Ibid, 1999: 46). Penelitian ini menggunakan metode deskriptif analisis. Data yang diperoleh seperti hasil pengamatan, hasil wawancara, hasil pemotretan, analisis dokumen, catatan lapangan, dari semua data dan informasi yang diperlukan berkenaan dengan pertanyaan apa, mengapa, dan bagaimana untuk mengungkap proses bukan semata-mata mengungkap hasil suatu kegiatan. Pertanyaan tersebut menuntut gambaran nyata tentang kegiatan, prosedur, alasan-alasan, dan interaksi yang terjadi dalam konteks koreografi bagaimana ekspresi seorang penari baik tunggal maupun kelompok pada saat virtuositas penari yang diamati dari perspektif budaya visualisasi photomotion. Proses itu berlangsung secara alamiah dibiarkan terjadi tanpa intervensi peneliti, sebab proses yang terkontrol akan menggambarkan keadaan mendekati objek yang sebenarnya. Peneliti akan mentransformasikan data menjadi informasi makna yang telah diperoleh. Makna suatu proses dimunculkan konsep-konsepnya untuk membuat prinsip bahkan teori sebagai suatu temuan atau hasil penelitian ini.

\section{HASIL DAN PEMBAHASAN}

Pada dasarnya penari tunggal terkait dengan kreativitas eksplorasi tubuh dalam pengembaraan dan penciptaan tari. Kemampuan penari tunggal seperti, di antaranya corporal impulses, corporal acrobatic, corporal instinc semestinya telah mencapai puncak virtuositasnya. Eksplorasi penari tunggal dalam aktivitas raga adalah penggalian potensi nurani manusiawi dan potensi murni lingkungan serta sarana dengan sentuhan estetika, yang hasil 
eksplorasinya masih melintasi tahap penjejakan alternatif untuk divisualisasikan dalam photomotion tari rampak kelompok. Awal sentuhan yang dilakukan adalah dengan penumbuhan kesadaran atas potensi murni dari daya pesona, daya ungkap, dan daya jangkau. Ketiga potensi murni tersebut tidak membutuhkan bakat apresiasi untuk memilikinya, sebab sudah ada sebelumnya. Kemurnian potensi seperti inilah yang jadi orientasi utama dari sebuah eksplorasi tubuh. Keterpaduan dari keindahan yang tertangkap inderawi dengan topangan nalar melalui pelebaran yang sistematis inilah sebagai awal langkah dari sebuah eksplorasi diri dan nilai kemanusiaan serta alam, berproses jadi satu dalam sifat tando tabalah (identitas pribadi).

Sebuah karya tari lahir disebabkan adanya ide atau gagasan yang muncul atas pemikiran dari penata tari dalam menciptakan sebuah tarian.
Ide, isi, atau gagasan ialah bagian dari tari yang terlihat, yang merupakan hasil pengaturan unsurunsur psikologis dan pengalaman emosional (Murgiyanto, 1982:23). Berdasarkan pernyataan tersebut, kemampuan penari untuk menciptakan dan merealisasikanide yang tumbuh dalam benaknya untuk diwujudkan di ruang publik. Karya tari adalah hasil dari sebuah proses penciptaan, melalui kreativitas tersebut seniman dapat mentransformasikan pengalaman batinnya ke dalam sebuah karya seni yang akan dikomunikasikan kepada orang banyak. "Seniman adalah seorang pengumpul kesan-kesan, seorang super sensitive yang terlatih dalam mengamati benda dan peristiwa-peristiwa di sekelilingnya yang oleh kebanyakan orang tidak diperhatikan (Murgiyanto, 2004: 49).

Tabel 1. Perbandingan Gerak Bentuk (Garak) dan Gerak Rasa (Garik)

\begin{tabular}{|c|c|c|c|}
\hline No. & Nama Gerak & $\begin{array}{c}\text { Gerak Bentuk } \\
\text { (Garak) }\end{array}$ & $\begin{array}{c}\text { Gerak Rasa } \\
\text { (Garik) }\end{array}$ \\
\hline 1 & Rantak Kudo & Alua, Patuik & Raso Pareso \\
\hline 2 & Pitunggua tangah & Alua, Patuik & Raso Pareso \\
\hline 3 & Tupai bagaluik & Alua, Patuik & Raso Pareso \\
\hline 4 & Langkah injak baro & Alua, Patuik & Raso Pareso \\
\hline 5 & Pancuang ateh bawah & Alua, Patuik & Raso Pareso \\
\hline 6 & Sambah bumi & Alua, Patuik & Raso Pareso \\
\hline 7 & Galitiak tangan & Alua, Patuik & Raso Pareso \\
\hline 8 & Silek balabeh tagak alif & Alua, Patuik & Raso Pareso \\
\hline 9 & Bungo ateh & Alua, Patuik & Raso Pareso \\
\hline 10 & $\begin{array}{l}\text { Sambah bumi dan sambah } \\
\text { penonton }\end{array}$ & Alua, Patuik & Raso Pareso \\
\hline 11 & Alang tabang & Alua, Patuik & Raso Pareso \\
\hline 12 & Fleksi bawah & Alua, Patuik & Raso Pareso \\
\hline 13 & Oyak kanan dan oyak kiri & Alua, Patuik & Raso Pareso \\
\hline 14 & Tagaik itiak & Alua, Patuik & Raso Pareso \\
\hline 15 & Rotasi Putaran & Alua, Patuik & Raso Pareso \\
\hline 16 & Sudueng & Alua, Patuik & Raso Pareso \\
\hline 20 & Allau & Alua, Patuik & Raso Pareso \\
\hline 21 & Tangkok & Alua, Patuik & Raso Pareso \\
\hline 22 & Sijundai & Alua, Patuik & Raso Pareso \\
\hline
\end{tabular}


budaya dan suku bangsa pendukungnya. Modus stilisasi semacam ini sudah mengandung komentar atau sikap yang jelas dari budaya atau (suku) bangsa pemiliknya. Situasi berubah sesuai dengan perkembangan budaya tuntutan zaman atau sejarah: ketika sekelompok manusia berpindah tempat atau meniti waktu. Maka wajar jika tari Minangkabau tahun 1950-an sangat berbeda dengan tari Minangkabau kontemporer yang ada saat ini. Demikian juga, tari Jawa awal abad ke-20 berbeda dengan tari Jawa awal abad ke-21. Bahkan, bagi para ahli, tak sulit menemukan beda antara tari Jawa gaya Surakarta dan gaya Yogyakarta dari kurun waktu yang sama. Dengan uraian ini ingin ditegaskan bahwa rasa keindahan itu berbeda dari satu zaman ke zaman yang lain, dari satu tempat ke tempat yang lain, dan dari satu budaya ke budaya lain, sekalipun ada elemen atau aspek-aspeknya yang berlaku universal. Stilisasi berbeda sesuai dengan perbedaan waktu dan tempat. Akan tetapi dari sudut pandang estetika pertunjukan, setiap stilisasi menuntutkejelasan bentukdan kaitan atau dukungannya terhadap citra yang hendak diwujudkan. Stilisasi gerak yang jelas dan konsisten akan menghasilkan style atau gaya pertunjukan tari yang terkait dengan daerah budaya, kurun waktu, atau pribadi penata tari. Mengutip Lincoln Kirstein (via Cohen, 1968: 87), tarian yang disajikan di atas panggung profesional haruslah 'theatrically legible'. Tuntutan ini dipenuhi dengan stilisasi: "The purely natural gesture has sufficient meaning for the performer, but for the audience its fails to establish a theatrically perceivable image."

\section{Tubuh Kekuatan Inspirasi dan Sumber Eksplorasi}

Gerakan tari membangkitkan rasa keindahan karena dirancang tidak hanya sekadar menghadirkan gerak maknawi. Oleh karena alat ungkapnya adalah tubuh manusia, maka sejak lama keindahan badani atau sensuous beauty menjadi salah satu daya pikat berbagai jenis tarian. Menurut Holt ciri khusus tarian Indonesia adalah terikat dengan tanah dan tidak menjauhinya. Posisinya duduk, berlutut, membungkuk ataupun setengah bungkuk (LIPI, 1984: 117). Hal ini dapat dilihat dari gerak pemotretan terhadap Alfyanto, Dadan, Oneng, Komalasari, dan Yeni Yunita. Dari beberapa karya foto hasil bidikan pada adegan-adegan tertentu, secara corporal impulses tanpa disadari ataupun disadari dengan kreatif, ada beberapa ciri garik garinyiak yang memberikan kesan sekilas tetapi membekas dalam pengamatan terhadap gerak tersebut, seperti loncatan tinggi dengan kaki membuka lebar kemudian jatuh ke bawah dengan tempo cepat dan langsung berdiri, badan melayang dengan lembut dalam tempo cepat rebah ke bawah, angkatan kaki yang ringan walau posisi kaki pitunggue (disebut juga kuda-kuda). Pembentukan kedua kaki ditekuk baik dalam pitunggue tengah, kanan, kiri, belakang atau, pitunggue depan harus kuat dalam sikap berdiri. Oleh karena itu ciri-ciri tari Minang penggunaan istilah pitunggue, karena silatnya ditikberatkan pada bagian bawah) putaran badan dengan kaki sebagai sumbu (poros) maupun putaran badan yang hanya diikuti bahu dan kepala dengan gerak sentak yang mengejutkan, gerak rantak kaki yang cepat, padat, dan kuat. Ragam gerak dalam tari Minang bersumber dari pencak silat (Murgiyanto, 1991: 274) atau dengan kata lain Alfyanto dkk. mempunyai kemampuan untuk 'bermain' dengan elemenelemen yang familiar dan menatanya secara tidak familiar dengan menarik, yang cukup memberikan sumber inspirasi dalam bereksplorasi.

Gaya tari Minang pada umumnya 'menapak ke bumi'. Artinya, konsep tarian itu dipola untuk ditarikan dengan tancapan kaki pitunggue yang kuat dan lutut merendah. Jarang sekali ditemukan angkatan kaki secara berlama-lama dan jika gerakan itu diulang, pengulangan tidak dalam intensitas yang tinggi. Kalaupun ada, gerakan mengangkat kaki itu (kiri atau kakan), biasanya hanya terjadi dalam hitungan detik. Jika kaki itu diangkat, penari selalu dengan segera menginjakkan kakinya kembali ke 'bumi'. Misalnya pada gerak angkatan kaki sabetan dalam tari Jawa atau jangkung ilo dalam tari Sunda. Tancapan kaki, atau dalam istilah geraknya disebut pitunggue, adeg-adeg, atau kuda-kuda, dalam Pencak Silat, justru dijadikan salah satu ukuran baik-tidaknya kriteria seorang penari. Fenomena ini tidak saja terdapat di dalam tarian Minang, Jawa, dan Sunda, akan tetapi juga banyak ditemukan dalam tarian di belahan dunia lainnya, terutama di Asia, lebih khusus lagi di Asia Tenggara. Berbeda dengan balet yang gerak kakinya lebih terkesan mengambang dan senantiasa meringankan tubuhnya seperti ingin terbang. Tumpuan tubuh penarinya berada pada ujung jari-jari kaki. Tarian di Indonesia, berat tubuh penari justru bertumpu di telapak kaki, kiri atau kanan, atau kedua-duanya. 
budaya dan suku bangsa pendukungnya. Modus stilisasi semacam ini sudah mengandung komentar atau sikap yang jelas dari budaya atau (suku) bangsa pemiliknya. Situasi berubah sesuai dengan perkembangan budaya tuntutan zaman atau sejarah: ketika sekelompok manusia berpindah tempat atau meniti waktu. Maka wajar jika tari Minangkabau tahun 1950-an sangat berbeda dengan tari Minangkabau kontemporer yang ada saat ini. Demikian juga, tari Jawa awal abad ke-20 berbeda dengan tari Jawa awal abad ke-21. Bahkan, bagi para ahli, tak sulit menemukan beda antara tari Jawa gaya Surakarta dan gaya Yogyakarta dari kurun waktu yang sama. Dengan uraian ini ingin ditegaskan bahwa rasa keindahan itu berbeda dari satu zaman ke zaman yang lain, dari satu tempat ke tempat yang lain, dan dari satu budaya ke budaya lain, sekalipun ada elemen atau aspek-aspeknya yang berlaku universal. Stilisasi berbeda sesuai dengan perbedaan waktu dan tempat. Akan tetapi dari sudut pandang estetika pertunjukan, setiap stilisasi menuntutkejelasan bentukdan kaitan atau dukungannya terhadap citra yang hendak diwujudkan. Stilisasi gerak yang jelas dan konsisten akan menghasilkan style atau gaya pertunjukan tari yang terkait dengan daerah budaya, kurun waktu, atau pribadi penata tari. Mengutip Lincoln Kirstein (via Cohen, 1968:

87), tarian yang disajikan di atas panggung profesional haruslah 'theatrically legible'. Tuntutan ini dipenuhi dengan stilisasi: "The purely natural gesture has sufficient meaning for the performer, but for the audience its fails to establish a theatrically perceivable image."

\section{Tubuh Kekuatan Inspirasi dan Sumber Eksplorasi}

Gerakan tari membangkitkan rasa keindahan karena dirancang tidak hanya sekadar menghadirkan gerak maknawi. Oleh karena alat ungkapnya adalah tubuh manusia, maka sejak lama keindahan badani atau sensuous beauty menjadi salah satu daya pikat berbagai jenis tarian. Menurut Holt ciri khusus tarian Indonesia adalah terikat dengan tanah dan tidak menjauhinya. Posisinya duduk, berlutut, membungkuk ataupun setengah bungkuk (LIPI, 1984: 117). Hal ini dapat dilihat dari gerak pemotretan terhadap Alfyanto, Dadan, Oneng, Komalasari, dan Yeni Yunita. Dari beberapa karya foto hasil bidikan pada adegan-adegan tertentu, secara corporal impulses tanpa disadari ataupun disadari dengan kreatif, ada beberapa ciri garik garinyiak yang memberikan kesan sekilas tetapi membekas dalam pengamatan terhadap gerak tersebut, seperti loncatan tinggi dengan kaki membuka lebar kemudian jatuh ke bawah dengan tempo cepat dan langsung berdiri, badan melayang dengan lembut dalam tempo cepat rebah ke bawah, angkatan kaki yang ringan walau posisi kaki pitunggue (disebut juga kuda-kuda). Pembentukan kedua kaki ditekuk baik dalam pitunggue tengah, kanan, kiri, belakang atau, pitunggue depan harus kuat dalam sikap berdiri. Oleh karena itu ciri-ciri tari Minang penggunaan istilah pitunggue, karena silatnya ditikberatkan pada bagian bawah) putaran badan dengan kaki sebagai sumbu (poros) maupun putaran badan yang hanya diikuti bahu dan kepala dengan gerak sentak yang mengejutkan, gerak rantak kaki yang cepat, padat, dan kuat. Ragam gerak dalam tari Minang bersumber dari pencak silat (Murgiyanto, 1991: 274) atau dengan kata lain Alfyanto dkk. mempunyai kemampuan untuk 'bermain' dengan elemenelemen yang familiar dan menatanya secara tidak familiar dengan menarik, yang cukup memberikan sumber inspirasi dalam bereksplorasi.

Gaya tari Minang pada umumnya 'menapak ke bumi'. Artinya, konsep tarian itu dipola untuk ditarikan dengan tancapan kaki pitunggue yang kuat dan lutut merendah. Jarang sekali ditemukan angkatan kaki secara berlama-lama dan jika gerakan itu diulang, pengulangan tidak dalam intensitas yang tinggi. Kalaupun ada, gerakan mengangkat kaki itu (kiri atau kakan), biasanya hanya terjadi dalam hitungan detik. Jika kaki itu diangkat, penari selalu dengan segera menginjakkan kakinya kembali ke 'bumi'. Misalnya pada gerak angkatan kaki sabetan dalam tari Jawa atau jangkung ilo dalam tari Sunda. Tancapan kaki, atau dalam istilah geraknya disebut pitunggue, adeg-adeg, atau kuda-kuda, dalam Pencak Silat, justru dijadikan salah satu ukuran baik-tidaknya kriteria seorang penari. Fenomena ini tidak saja terdapat di dalam tarian Minang, Jawa, dan Sunda, akan tetapi juga banyak ditemukan dalam tarian di belahan dunia lainnya, terutama di Asia, lebih khusus lagi di Asia Tenggara. Berbeda dengan balet yang gerak kakinya lebih terkesan mengambang dan senantiasa meringankan tubuhnya seperti ingin terbang. Tumpuan tubuh penarinya berada pada ujung jari-jari kaki. Tarian di Indonesia, berat tubuh penari justru bertumpu di telapak kaki, kiri atau kanan, atau kedua-duanya. 


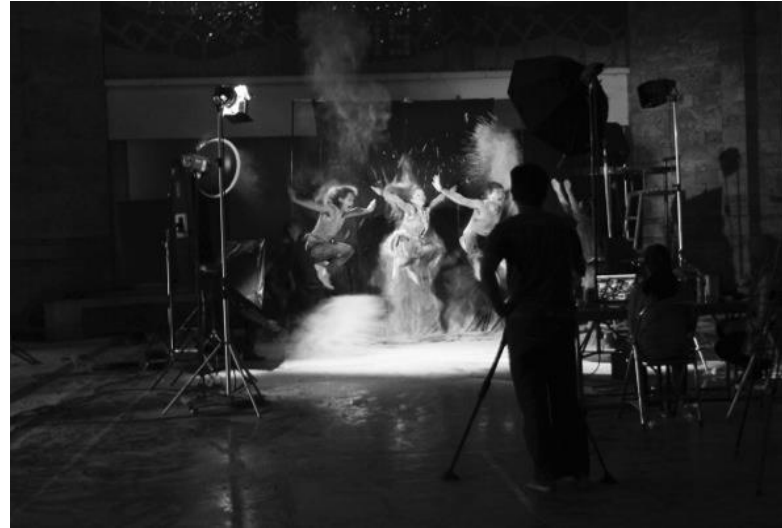

Gambar 1. Proses Pemotretan, Fotografer : Andang Iskandar



Gambar 2. Hasil Pemotretan, Fotografer : Andang Iskandar

Menurut Bakhtin, bahwa tubuh sebagai sesuatu yang terbuka dan belum selesai, terus-menerus berubah dan diperbaharui; tubuh adalah sebuah citraan yang dinamis. Tubuh grotesk adalah 'daging sebagai tempat berproses'. Tubuh tidak dipahami sebagai sesuatu yang individual melainkan sesuatu yang universal (Derks, $[t . t]$ : 83). Dalam proses koreografi sering kali identitas suatu karya dipengaruhi oleh faktor lingkungan maupun sarana. Tetapi bagaimana pun besarnya pengaruh lingkungan, ciri-ciri pribadi khususnya pribadi koreografernya akan nampak pada koreografinya. Dalam proses ini tak dapat dipungkiri adanya laku kreatif yang seringkali bersifat misterius, di mana kegiatan kreatif itu pada dasarnya bersifat subjektif dan pribadi (Hadi, 1996: 39). Meskipun tampil sebagai individu namun tetap mempunyai latar belakang keluarga dan lingkungan yang ikut terlibat menentukan apa yang terjadi sekarang ini. Hal ini sesuai dengan konsep psikologi tentang interaksi terus menerus antara keturunan dan lingkungan yangdikemukakan oleh Donald Heb, bahwa faktor keturunan dan faktor lingkungan berinteraksi terus menerus dalam membentuk perkembangan dan kepribadian seseorang (Davidoff, 1988: 81).

Meditasi adalah konsentrasi pada diamnya diri sendiri, atau pada jiwa diri sendiri, atau pada kebenaran yang lebih tinggi, yakni nama-nama dan sifat-sifat Allah (Muthahhari, 1995:127). Selanjutnya, dalam buku Rumi, Menatap Sang Kekasih, Will Johnson secara jeli memandang bahwa:

Untuk menjadi penari sejati, Anda harus menjadi sadar sedekat-dekatnya dengan tubuh Anda, merasakan setiap bagian kecil beserta semua cara bagaimana bagian itu ingin bergerak. Ketika kita ingin menahan bagian kecil tubuh kita, secara efektif kita menumpulkan kesadaran kita atas sensasi-sensasi tubuh. Ketika kita pasrah pada arus sensasi tubuh yang ingin mengalir melalui kita seperti air melalui sebuah pintu air, tubuh mungkin secara spontan mulai bergerak dan menari, karena memang begitulah cara alami untuk mengekspresikan kenikmatan yang nyata. Seorang penari benar-benar menjadikan tubuh nya sebagai teman, hingga setiap bagian dan bidang yang kecil, tidak ada yang terlewat, tidak pula seutas serat otot, tidak juga satu sensasi, tidak pula satu gerakan; inilah persahabatan sejati (2003:87-88).

Seorang penata tari berkarya untuk memenuhi desakan batin dan menciptakan wujud-wujud baru yang merupakan hasil tanggapannya yang khas terhadap pengalaman hidup. Sementara satu sisi naluriah manusia memaksa orang bertahan untuk menjadi bagian penting dari budaya sendiri dan memelihara tradisi, sisi lainnya mengajak manusia membongkar bentuk-bentuk budaya yang mapan untuk menemukan cara-cara mengungkapkan pengalaman hidup dengan cara baru. Bagaimana seorang penata tari mengembangkan potensi kreatifnya dipengaruhi oleh lingkungan di mana ia tinggal dan interaksinya dengan dunia di sekitarnya. Dalam hidupnya, secara terus-menerus manusia silih berganti menghadapi dunia lahir dan dunia batin. Penyerapan elemen dari luar tubuh bukan hanya dilakukan untuk mengonsumsi kebutuhan dasar hidup seperti udara dan nutrisi untuk bertahan hidup, tetapi juga masukan sensoris atau inderawi. Masukan-inderawi (visual, aural, tactile, dan kinestetic) membantu kita menghayati dunia sekitar: alam, benda-benda, manusia, dan peristiwa. Masukan inderawi menstimulasi alam batin yang mendorong kita untuk bertindak. 
Melalui proses penyerapan semacam inilah manusia memperkaya pengalamannya dan melalui proses mengungkapkan kembali, manusia mengekspresikan penemuan-penemuannya.

Aliran masukan-inderawi yang tak pernah putus dari dunia luar membuat orang merasa perlu memadu dan menata elemen-elemen atau fragmen pengalaman yang ditemuinya dalam kehidupan sehari-hari yang terpisah-pisah ke dalam hubungan yang saling menunjang dan bermakna. Proses inilah yang disebut simbolisasi, yaitu penataan secara runtut pengalaman-pengalaman manusia. Potensi kreatif yang dimiliki oleh setiap orang dan kebutuhan setiap manusia akan bentuk merupakan faktor utama terwujudnya sebuah bentuk seni. Kemampuan kreatif setiap orang harus dihargai dan dikembangkan melalui kegiatan yang mandiri (yang arah dan keberhasilannya ditentukan oleh pelakunya sendiri) di dalam sebuah suasana yang suportif dan non-judgmental.

Di dalam tari, praktik improvisasi digunakan untuk berbagai tujuan, yang terpenting adalah sebagai langkah atau tahap penting di dalam proses kreativitas penciptaan karya tari. Tetapi pada umumnya disetujui bahwa untuk dapat berjalan dengan baik, improvisasi tari menuntut kelenturan dan kekuatan baik mental maupun fisikal. Sejak tahun 1970-an, sejumlah penari Amerika menggunakan gerakgerak improvisasi sebagai alternatif dari pre-set koreografi. Ann Halprin dan Yvonne Rainer adalah dua contohnya. Tetapi pengembang gagasan improvisasi sebagai suatu bentuk tari yang paling dikenal adalah Steve Paxton dkk. yang menemukan contact improvisation. Dalam kontak-improvisasi, sensing (kepekaan indera) menjadi tumpuan/ motivasi gerak penari menggantikan preset intention (tujuan yang ditentukan sebelumnya). Hasil yang hendak dicapai adalah menemukan gerak-gerak yang bebas dari konvensi atau aturan yang ada. Sikap dan kondisi fisik yang baik menjadi prasyarat untuk menghindari cedera dan mencapai hasil yang diinginkan. Saling percaya dan menyadari posisi masingmasing sangat perlu untuk melakukan kontakimprovisasi dengan aman. Di samping itu inwardfocus atau fokus ke dalam adalah salah satu ciri kontak-improvisasi. Jika dalam pertunjukan biasa kita melakukan sesuatu untuk penonton, para penari dalam kontak improvisasi memusatkan perhatiannya pada hubungan dan antisipasi pada apa yang (akan) terjadi di antara mereka.

\section{SIMPULAN}

Berawal dari sebuah aistanomai 'saya menyadari sesuatu' yang mengangkat filosofi Minang aparapa untuk menjadi sebuah konsep estetik tari Minang, karena pada dasarnya konsep estetik sebagai ilmu dapat terwujud sebagai proses, aktivitas rasional, dan aktivitas kognitif. Estetika aparapa berkaitan dengan nilai-nilai tertentu. Nilai yang dimaksud adalah dalam upaya mencari suatu kelayakan (feasible: able to become fact). Oleh karena itu, dalam kreativitas penciptaannya bersendi pada: (1) keindahan (beauty); (2) kebaikan (good); serta (3) kebenaran (truth). Estetika dipandang sebagai suatu filsafat yang ditempatkan pada titik dikotomis antara realitas dan abstrak, juga antara keindahan dan makna. Fenomena visual dalam konteks penelitian ini adalah mengacu pada konsep estetik dalam konteks transendental (kebenaran, kebaikan, dan keindahan), artinya konsep yang diadopsi dari kearifan lokal dalam masyarakat Minangkabau yaitu filosofi aparapa. Kebenaran perilaku yang berdasarkan pada konsep nilai-nilai budayanya merupakan suatu kebaikan yang akan menghasilkan keindahan dalam tatanan keselarasan dan harmoni. Ragam gerak yang yang dipilih sebagai model untuk analisis tidak hanya pada sekedar hiasan keindahan gerak belaka (tangibel), namun ia dapat diterjemahkan, sekaligus merupakan simbol atau lambang yang bermakna mendidik (intangibel), dan dapat menjadi teladan dalam kehidupan sehari-hari dalam masyarakat adat di Minangkabau.

Secara keseluruhan dalam pengkajian analisis gerak, desain yang sering digunakan yaitu: desain lengkung, desain lurus, desain sudut, desain kontras, desain simetri, dan desain asimetri. Adapun gesture yang sering melekat pada gerak galombang randai yaitu gesture sosial dan gesture fungsional. Pencak silat menjadi sumber estetika aparapa yang banyak menggunakan gerak serang tangkis (gesture fungsional) untuk mempertahankan diri, untuk penghormatan atau upacara (gesture ritual), dan untuk menggambarkan ekspresi (gesture emosional), akan tetapi di samping itu bentuk gerak juga merupakan realitas yang mudah dipahami (gesture sosial) dalam kehidupan sehari-hari. 
Analisis gerak, tidak dapat dilepaskan dari persoalan tentang tanda dan struktur tanda (semiotika) yang membangunnya. Semiotika bentuk gerak sebagai sebuah tanda yang dapat ditangkap oleh penulis baik sebagai fungsi semiotik parodi maupun fungsi metafora dalam seni. Rasa keindahan timbul karena peran dari panca indra, yang memiliki kemampuan untuk menangkap rangsang dari luar dan meneruskannya ke dalam, hingga rangsangan itu diolah menjadi kesan. Kesan itu dilanjutkan lebih jauh ke tempat tertentu di mana perasaan bisa menikmatinya. Penangkapan kesan dari luar, yang menimbulkan nikmat-indah terjadi melalui dua dari lima jenis panca indra kita, istilah dalam ilmu seni, yakni melalui mata dan telinga baik secara langsung maupun tidak langsung diterima menjadi sebuah sensasi-persepsi-impresi-emosi-interpretasidan ekspresi.

\section{DAFTAR RUJUKAN}

Carter, Curtis L. 2000 "Improvisation in Dance. "Journal of Aesthetics and Art Criticism 58:2, Spring.

Cohen, Selma Jean. 1968 "A Prolegomenon to an Aesthetic of Dance," dalam Lee A. Jacobus, ed., Aesthetics and the Arts. New York: McGraw-Hill.

Davidoff, Linda L. 1988 Psikologi Suatu Pengantar. Jakarta: Erlangga.

Derks, Will. [t. th. ] "Tubuh Liar: Realisme Grotesk dalam Cerita Melayu", dalam Kalam: Menguak Tubuh. Jakarta: Yayasan Kalam.

Krasner, Jon. 2008. Motion Graphic Design : Applied History and Aesthetics. Oxford : Focal Press

LIPI. 198 Kapita Selekta Manifestasi Budaya Indonesia. Bandung: Badan Penelitian dan Pengembangan Departemen Luar Negeri bekerja sama dengan Penerbit Alumni.

Murthada Muthahhari 2014 Falsafah Kenabian, Monoteisme, Teoretis. Jogyakarta: Rausyanfikr
R. M. Soedarsono 2004 Seni Pertunjukan Dari Perspektif Politik, Sosial, dan Ekonomi. Yogyakarta: Gadjah Mada University Press.

2002 Seni Pertunjukan Indonesia di Era Globalisasi. Yogyakarta: Gadjah Mada University Press.

1999 Metodologi Penelitian Seni Pertunjukan \& Seni Rupa. Bandung: MSPI.

1991 "Seni diIndonesia: Kontinuitas dan Perubahan". Terjemahan. Art in Indonesia: Continuitas and Change, ClaireHolt. Yogyakarta: ISI Yogyakarta.

Sal Murgiyanto 2004 Mencermati Seni Pertunjukan: Perspektif Kebudayaan, Ritual, Hukum. Surakarta: Kerjasama Ford Foundation\& Program Pascasarjana ISI Surakarta.

1991 "Minangkabau Dance Redefined: 1968 -1971", dalam Disertasi Moving Between Unity and Diversity, Four Indonesian Choreographers. New York: New York University.

1982 Penata Tari Muda. Jakarta: PT Harapan/Dewan Kesenian.

Y. Sumandiyo Hadi 1996 Aspek-aspek Dasar Koreografi Kelompok. Yogyakarta: Manthili. 